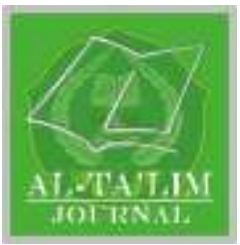

AL-TA'LIM JOURNAL, 24 (2), 2017, (130-141)

(Print ISSN 1410-7546 Online ISSN 2355-7893)

Available online at http://journal.tarbiyahiainib.ac.id/index.php/attalim

\title{
The Content Mastery among Islamic Education Teachers in Junior Islamic Secondary Schools in Surakarta
}

\author{
Received: $25^{\text {th }}$ March 2017; Revised: $21^{\text {st }}$ April 2017; Accepted: $15^{\text {th }}$ July 2017 \\ Permalink/DOI: http://dx.doi.org/10.15548/jt.v24i2.274
}

\section{Muhammad Munadi}

Institut Agama Islam Negeri Surakarta, Indonesia

E-mail: munadimahdiputra@gmail.com

\begin{abstract}
The study aims to describe the content mastery among Islamic Education teachers in all MTs/N (Islamic Secondary School) located in Surakarta. A mixed method was used in this study, where the teachers of MTsN and private MTs in Surakarta involved in this study. Test, interview and documentation became the instruments of this study. For ensuring the validity, the researcher used expert judgment. The data was analyzed by using descriptive statistics. The results of the study showed that in overall the average scores in the Islamic Education materials had been 74 - which was quite low for a teacher. Meanwhile, some of the teachers got only 47 as compared to 100 for the maximum score. From four subjects in the Islamic Education, the score of the teachers' academic test from the highest to the lowest would be displayed as follows: Qur'an Hadits were 76.40; Fiqh was 76.40; SKI was 73.46; and Aqidah Akhlak was 72.40. It Indicated that the content mastery in the Qur'an - Hadits and Aqidah Akhlak had been higher than that of Fiqh and SKI.
\end{abstract}

Keyword: Content mastery, teachers, Islamic Education

How to Cite: Munadi, M. (2017). The Content mastery among islam education teachers in Junior Islamic Secondary Schools in Surakarta. Al-Ta Lim Journal, 24 (2). doi:http://dx.doi.org/10.15548/jt.v24i2.274

\section{INTRODUCTION}

In terms of background, most of Islamic Education teachers have been generated from the process of teacher education and development in the Islamic Education Study Program among the State/Private Islam University (PTKIN, Perguruan Tinggi Keagamaan Islam Negeri/PTKIS, Perguruan Tinggi Keagamaan Islam Swasta). Both institutions generate the Islam Education teachers who in general will serve their duty in the schools under the appointment of the Ministry of Education and Culture. For the Madrasah schools that have been coached by the Ministry of Religion, the process of educating the Islam Education teachers based on the Islamic Education Study Program has not been appropriate due to the abundant types of Islamic Education learning materials. The general Islamic Education teachers should teach the specific Islamic Education, namely that they should be the teachers of Qur'an Hadits, Aqidah Akhlak, Fiqh and the History of Islamic Cultures (SKI, Sejarah Kebudayaan Islam). This matter has caused the performance of Islamic Education Study Program-graduated teachers to be low in their workplace. Many teachers in the schools and in the madrasah have been identified to be less professional, to have low performance and to have low enthusiasm in developing their self-capacity (Abdurrahmansyah, 2014; Azra, Afrianty, \& Hefner, 2007; Kong, 2005). Multiple weaknesses that these educating forces have, in certain aspects, cannot be 
separated from the pattern of their education and development in the Institution of LPTK. The development of teacher candidates in the Institution of Teaching Staff Education Indonesian Teaching Staff Education (LPTK PTKI, Lembaga Pendidikan Tenaga Keguruan Pendidikan Tenaga Keguruan Indonesia) in general has been conducted by means of pedagogical content knowledge (PCK) rather than content knowledge (CK) (Gess-Newsome \& Lederman, 2001; Hill, Ball, \& Schilling, 2008; Koehler \& Mishra, 2005; Loewenberg Ball, Thames, \& Phelps, 2008; Mishra \& Koehler, 2006; Munadi, Choiriyah, \& Alawiyah, 2016; Niess, 2005). Actually, both approaches should be in harmony from one to another. With regards to this situation, Kleickmann et al. (2013) stated that pedagogical content knowledge (PCK) and content knowledge (CK) are key components of teacher competence that affect student progress. In the meantime, the teachers' content knowledge is very important in order to improve their teaching and learning process; however, this aspect has rarely been a focus of attention among the researchers. Even, historically most of the researchers focus on the aspects of teaching process in comparison to that of teachers' understanding toward the subjects that they have been teaching (Loewenberg Ball et al., 2008; Putnam \& Borko, 2000; Schunk, Meece, \& Pintrich, 2012).

According to several studies it has been found that the content mastery of both Mathematics teachers and Science teachers cause the difference in their learning practice and in their students' achievements (DarlingHammond, 2000; Guskey, 2002; Hill et al., 2008; Prawat, 1992; Shanahan \& Shanahan, 2008; Timperley, Wilson, Barrar, \& Fung, 2008). The teachers' content knowledge influences how the teachers involve the students in their learning materials, how the teachers evaluate and makes use of the learning materials and how the teachers; content knowledge is related to what the students have been learning.
The classification of Islamic Education teachers in the Madrasah, which consists of Al-Qur'an Hadits teacher, Aqidah Akhlak teacher, Fiqh teacher and History of Islamic Cultures teacher, is generated by the Islamic Education Study Program in the Faculty of Tarbiyah. From this classification, it might be apparent that the content mastery has been very weak because, according to the findings of several study such as the one by Munadi et al. (2016), it has been found that most of PTKI institutions have a curriculum that has been more dominated by the efforts of preparing the strong teacher candidates in terms of learning method, which has been known as pedagogical content knowledge (PCK), rather than in terms of content knowledge (CK). However, there are also Islamic Education teachers who have been generated by the institutions other than the Faculty of Tarbiyah and these teachers are supported by the license of teaching that they earn from the Akta IV Program. Unfortunately, this effort cannot boost quality of content mastery among the Islamic Education teachers as well. This case does not only occur in Madrasah Ibtidayah but also in Madrasah Tsanawiyah and Madrasah Aliyah.

According to Fägerlind \& Saha (2016) education in the future, including the development of Islamic Education in the schools, still demands intelligent teachers in terms of content mastery or content standards so that they will be able to develop the active, creative and innovative learning process. As an emphasis toward this direction, the teachers are demanded to master their major whereas they have been generated by educational institutions that prepare them to be a strong teacher in terms of teaching methodology.

On the other hand, the region of ExResidence of Surakarta includes 6 Regencies and 1 City and they are: Surakarta, Boyolali, Klaten, Karanganyar, Sukoharko, Sragen and Wonogiri. The wide coverage in the study urges the researcher to limit this area into two regions namely Surakarta and Sukoharjo. 
Based on the explanation above, the study then is to describe the level of Content Knowledge mastery among the groups of Islamic Education teacher in the Madrasah Tsanawiyah around Surakarta and Sukoharjo.

The study is a descriptive research that will be conducted in order to attain information regarding the content knowledge of Islamic Education teachers in the Madrasah Tsanawiyah around Surakarta and Sukoharjo, both the state ones and the private ones. The study was conducted in the even semester of the 2015/2016 Academic Year in both the State and the Private Madrasah
Tsanawiyah that has implemented the 2013 Curriculum within both regions. The subjects of the study then will be the groups of Islamic Education teachers in the eighth grade of both the State and the Private Madrasah Tsanawiyah in Surakarta and Sukoharjo. For the data collection, the researcher used Content Representation (CoRe) test for the groups of Islamic Education teachers, namely the Qur'an Hadits, Fiqh, the Aqidah Akhlak and the History of Islamic Cultures. The description of the test is provided in the following Table 1.

Table 1. The Content Representation (CoRe) of the Groups of Islamic Education Teachers

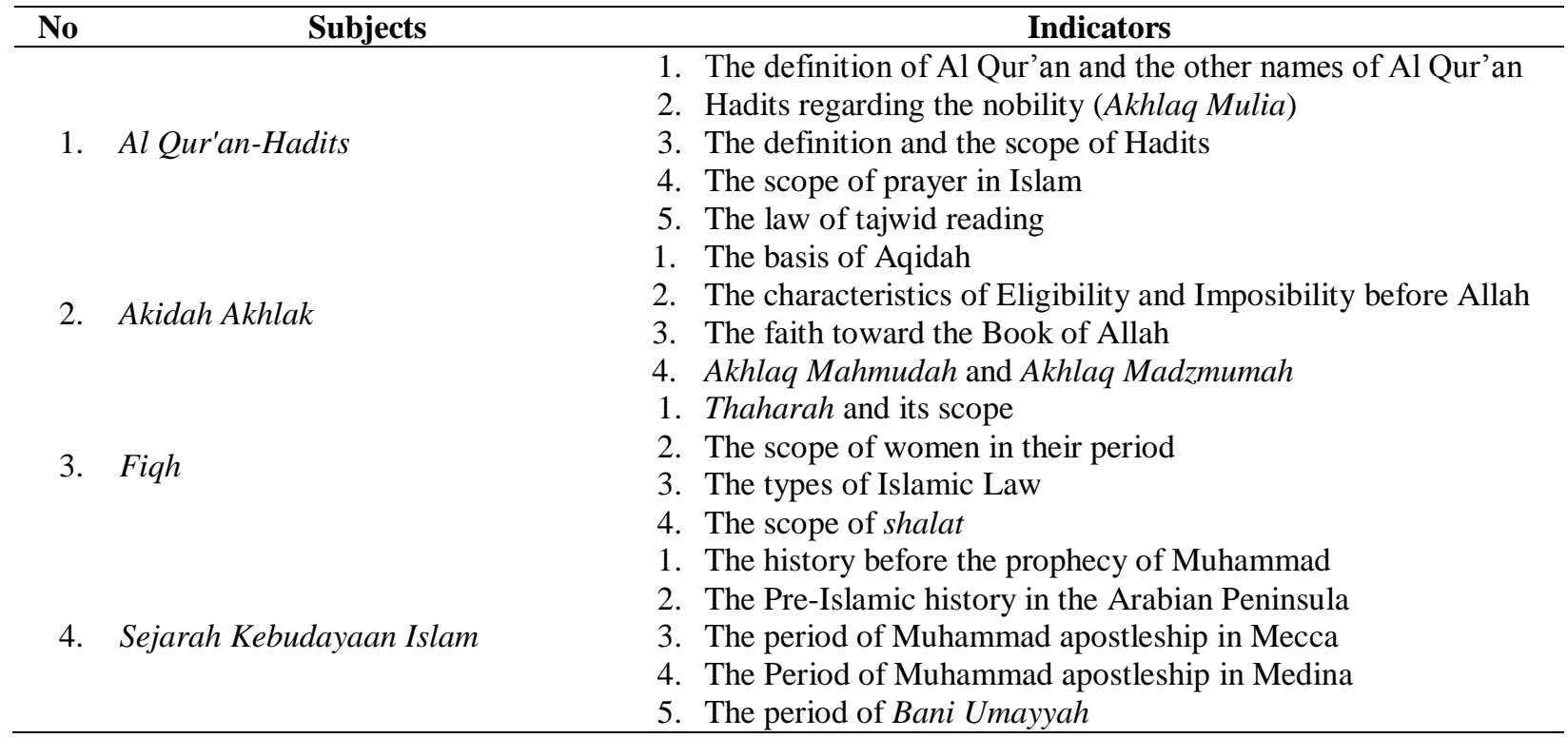

\section{Islamic Education in the Context of Curriculum}

Curriculum is a set of planning and arrangement regarding objectives, basic competencies, standard materials, learning results and manners that will serve as a guidance for learning activities implementation that have been designed in order to achieve the basic competencies and the educational objectives. The Government Regulation Number 19 Year 2005 Regarding the National Education Standard article 6 verses (1) states that the curriculum for the general, vocational and special education in the elementary and the high degree consists of:

1. The group of religion and nobility subjects;

2. The group of citizenship and personality subjects;

3. The group of science and technology subjects

4. The group of esthetics subjects; and

5. The group of physical education, sports and health subjects.

6. The coverage of the first group of subject will be provided in the Table 2 as follows: 
Table 2. The Scope for the Group of Religion and Nobility Subjects

\begin{tabular}{ll}
\hline \multicolumn{1}{c}{$\begin{array}{c}\text { Subject } \\
\text { Group }\end{array}$} & \multicolumn{1}{c}{ Scope } \\
\hline $\begin{array}{l}\text { Religion and } \\
\text { Nobility }\end{array}$ & $\begin{array}{l}\text { The subject group of religion and } \\
\text { nobility is intended to shape the } \\
\text { learning participants into individuals } \\
\text { who have faith and piety toward }\end{array}$ \\
& $\begin{array}{l}\text { Lord the Almighty and who have } \\
\text { nobility. Nobility entails ethics, } \\
\text { courtesy or morale as the } \\
\text { manifestation of religion education. }\end{array}$ \\
\hline
\end{tabular}

From the above scope, it is apparent that the religion education should be able to develop the students who have vertical nobility (Allah) as well as horizontal nobility (fellow human beings and Allah-designed creatures).

\section{Content Knowledge}

Harris, Mishra, \& Koehler (2009) stated that content knowledge is formed as a result of curriculum related work; that is, the designing and structuring of subject-specific contents for teaching. It embodies much more than just factual, everyday knowledge based on academic fundamentals.

The above statement implies that the content knowledge has been formed as the result of curriculum-related works. The implication of content knowledge turns makes an individual quite smart in designing and in structuring the specific subject contents for the teaching process. The coverage will be more than just mere facts and daily knowledge based on the academic fundamentals.

Similar definition was also provided by McNamara, as quoted by Cogill (2008); this definition suggests that knowledge of subject content is essential not only for teaching itself but also for the evaluation of text books, computer software and teaching aids. He also adds that teachers with strong $\mathrm{Ck}$ may teach in a more interesting and dynamic way whilst those with little CK may shy away from the more difficult aspects of the subject, or approach their teaching in a didactic manner.
This opinion shows that knowledge about the subject contents are not only intended for the mere teaching activities. Instead, the knowledge is intended for the wider activities such as evaluating text books, computer software and teaching aids. In addition, he also stated that teachers who have strong content knowledge might teach in a more interesting and dynamic way while those who have weak content knowledge might withdraw themselves from the more difficult aspects within the subjects.

Loewenberg Ball et al. (2008) divides several types of content knowledge as follows:

1. Common content knowledge: This is the type of knowledge which says that teachers have similarities to other people who have been educated within the knowledge subjects.

2. Curriculum knowledge: This is the type of knowledge that has been associated to certain parts of subject teachers that should be distributed to the students in certain grades, especially to the ones who will be tested. This includes the "knowledge horizon" regarding how the material subjects in the present class curriculum will be developed as a form of students' progress toward the higher grade and as the form of what they have studied in the previous grade.

3. Specialized content knowledge: This is the type of knowledge that has been associated to the specific learning materials for teaching activities. Usually these materials are taught by the highly trained teachers.

4. Knowledge of content and students: This is the type of knowledge that has been associated to how the students think, to what matter that might be confusing, to what matter that the students consider interesting and motivating and to what matter that the students that the students consider easy and difficult. This type of knowledge also listens and interprets that the students have not had complete reasoning and development. 
5. Knowledge of content and teaching: This is the type of knowledge that has been associated to the contents and the teaching activities that are related to the curriculum knowledge. However, this type of knowledge refers to more detailed knowledge regarding how to teach each aspect of the curriculum: what concept that should be introduced, how much the time should be allocated for test exercise or essay exercise for absorbing the concepts and for developing the practical experiences and alike.

The evidence that a teacher possesses the content knowledge will be as follows: a. Teacher content knowledge influences how teachers engage students with the subject matter.

b. Teacher content knowledge influences how teachers evaluate and use instructional materials.

c. Teacher content knowledge is related to what students learn. (Park \& Oliver, 2008)

The above indicators show that a teacher who masters the content knowledge should be strong in terms of subject pattern. In this context, an Islamic Education teacher should master:

Table 3. The Scope of Content Knowledge

\begin{tabular}{lccc}
\hline & \multicolumn{3}{c}{ The Scope of Content Knowledge } \\
\cline { 2 - 4 } $\begin{array}{c}\text { The Components of } \\
\text { Islamic Education }\end{array}$ & $\begin{array}{c}\text { Involving all students } \\
\text { into the learning } \\
\text { materials }\end{array}$ & $\begin{array}{c}\text { Evaluating and using the } \\
\text { learning materials }\end{array}$ & $\begin{array}{c}\text { What the students } \\
\text { had learned }\end{array}$ \\
\hline $\begin{array}{l}\text { Qur'an-Hadits } \\
\text { Fiqh }\end{array}$ & $\mathrm{V}$ & $\mathrm{V}$ & $\mathrm{V}$ \\
Aqidah Akhlak & $\mathrm{V}$ & $\mathrm{V}$ & $\mathrm{V}$ \\
History of Islam & $\mathrm{V}$ & $\mathrm{V}$ & $\mathrm{V}$ \\
Culture & $\mathrm{V}$ & $\mathrm{V}$ \\
\hline
\end{tabular}

The above table implies that a teacher should master four subjects altogether in the same time although the four subjects have different review. Certainly, the mastery of the four subjects becomes a peculiar difficulty for an Islamic Education teacher. Not to mention, the mastery of Arab language as a means for understanding the contents of Islamic Education becomes another difficulty.

The results of a study by Darmadji, Zubaidah, Sibly, \& Andriansyah (2015), who studied the Islamic Education in Yogyakarta, showed that the respondents have relatively low familiarity to the sources of Islamic law, especially the classic ones. These results also display the teachers' low content knowledge in terms of Islamic law-related matters especially the ones in the economy and the inheritance. This condition is caused by the fact that the mastery of classical books demands an individual to master the pattern of Arab language. The Islamic Education teachers are not prepared to deal with this interest.

Another study by Jones \& Moreland (2006) that has been published in their article entitled "Considering Pedagogical Content Knowledge in the Context of Research on Teaching: An Example from Technology" found that the good teachers' knowledge in terms of subject contents has been found to provide positive impact toward their decisionmaking process in relation to the change of pedagogical strategies for creating better learning situations. In addition, the content knowledge of voice seems to have positive impacts toward the planning, the curriculum planning, evaluation, implementation and development.

A study toward the Mathematics teachers by Copur-Gencturk \& Lubienski (2013); Gencturk, (2012) found that there is an advantage in the teachers' mathematical 
knowledge that has been predicted to become the change of their learning design quality, their mathematical agenda and their classroom atmosphere. The teachers' belief is related to the learning design quality, the mathematical agenda and the assignment quality that has been selected.

This study will be different than the three studies that have been mentioned in the previous sections in terms of review because this study will focus to the groups of Islamic Education in the Madrasah Tsanawiyah or MTs.

\section{METHOD}

A mixed method was used in this study. The population and the samples in the study were the teachers of state MTs and private MTs that in Surakarta and Sukoharjo. The data were gathered by means of test, interview and documentation. For ensuring the validity, the researcher made use of expert judgment. The data that had been attained would be analyzed by means of descriptive statistic technique with the qualitative descriptive reinforcement.

\section{RESULTS AND DISCUSSIONS}

\section{Sample Description}

The teachers who participated in the academic competence test were 31 peope from the State and the Private Madrasah Tsanawiyah around Surakarta and Sukoharjo. The number of the teachers who became the test participants should be higher than this figure; however, due to the fact that the schools were not open in providing information regarding the number of the teachers who taught the Islamic Education, the researcher had this low figure. Then, only some of the Islamic Education teachers had been able to complete the academic competence test and the others had only been able to complete the part of the test in which they had good capability. Therefore, there was slight difference in terms of subject number because this number was decided by the teachers who participated in the academic competence test.

The study was conducted in two sites, namely in the City of Surakarta and the Regency of Sukoharjo. From both regions, the researcher selected two Madrasah Tsanawiyahs, both the state ones and the private ones. The description of the selection would be provided in the following Table 4:

Table 4. Sample Description

\begin{tabular}{cllr}
\hline No & $\begin{array}{c}\text { Status of } \\
\text { Madrasah } \\
\text { Tsanawiyah }\end{array}$ & Region & Total \\
\hline 1. & State & Surakarta & 10 \\
2. & Private & Surakarta & 6 \\
3. & State & Sukoharjo & 4 \\
4. & Private & Sukoharjo & 11 \\
& & Total & $\mathbf{3 1}$ \\
\hline
\end{tabular}

This table showed that there had been a balance between the sample selection and the research site so that the research enabled to attain the proportionality. The proportionality should be attained in order that the study would have any bias both in terms of region and in terms of gender. The researcher, then, divided again the Table 4 into the gender of the teachers who became the respondents. In terms of gender, the description of these teachers would be as follows:

Table 5. Sample Description Based on the Gender

\begin{tabular}{rlr}
\hline No & \multicolumn{1}{c}{ Jenis Kelamin } & Jumlah \\
\hline 1. & Male & 20 \\
2. & Female & 11 \\
& Total & 31 \\
\hline
\end{tabular}

The number of male teachers had been higher than that of the female teachers. However, the overall number of teachers who became the sample in the study had been well distributed in both research sites. The description of this number would be as follows:

Table 6. Sample Description Based on the Madrasah Location

\begin{tabular}{clrrr}
\hline No & Gender & Surakarta & Sukoharjo & Total \\
\hline 1. & Male & 9 & 11 & 20 \\
2. Female & 7 & 4 & 11 \\
Total & $\mathbf{1 6}$ & $\mathbf{1 5}$ & $\mathbf{3 1}$ \\
\hline
\end{tabular}


The above description showed that the balance had been maintained in order that the preliminary principle of the study, namely to not have any bias both in terms of region and of gender, would be achieved.

On the other hand, the teachers' previous educational background might be viewed in the following data:

Table 7. Sample Description Based on the Educational Background

\begin{tabular}{rlr}
\hline No & \multicolumn{1}{c}{$\begin{array}{c}\text { Undergraduate Study } \\
\text { Program }\end{array}$} & Total \\
\hline 1. & Islamic Education & 30 \\
2. & Non-Islamic Education & 1 \\
& Total & 31 \\
\hline
\end{tabular}

This table showed that the academic competence test had been appropriate to be administered toward the Islamic Education teachers who had been graduated from the Islamic Education Study Program. However, the researcher still found a teacher who was not graduated from the Islamic Education Study Program despite the fact that he had been teaching the Islamic Education.

Furthermore, in terms of terms of service the researcher would like to display the following data:

Table 8. Sample Description Based on the Terms of service

\begin{tabular}{|c|c|c|}
\hline No & Terms of Service & Total \\
\hline 1. & $0-5$ years & 6 \\
\hline 2. & $6-10$ years & 9 \\
\hline 3. & $11-15$ years & 6 \\
\hline 4. & $16-20$ years & 6 \\
\hline 5. & $21-25$ years & 2 \\
\hline 6. & $26-30$ years & 1 \\
\hline & $31-35$ years & 1 \\
\hline & Total & 31 \\
\hline
\end{tabular}

In general, based on the terms of service these teachers had been teaching for less than 15 years. This situation was also reflected in the teachers' high enthusiasm because in average their chronological age had also been young. Most of the teachers had been 42 years old and the youngest teacher had been 26 years old.

\section{Description of Academic Competence Test}

In overall, the average score of Islamic Education material test had been 74 - which had been quite low for a teacher. Even, there were some teachers whose score had been 47 . The maximum score in the test was 100 . From the four subjects in the Islamic Education, the highest score up to the lowest score in terms of content mastery would be displayed as follows:

Table 9. Results of Content Mastery Test

\begin{tabular}{rlc}
\hline No & \multicolumn{1}{c}{ Subject } & Score \\
\hline 1. & Qur'an Hadits & 76.40 \\
2. & Fiqh & 76.40 \\
3. & History of Islamic & 73.46 \\
4. & Aquidare Akhlak & 72.40 \\
\hline
\end{tabular}

The samples within the study displayed quite low diversity in terms of content achievement under the Islamic Education subcomponents. From the 100 scale, the lowest score was reflected in the Aqidah Akhlak content and the highest score was reflected in the Qur'an-Hadits; meanwhile, the score on the other components reflected moderate mastery. A brief description on these results would be displayed in the following table:

Table 10. Achievement of the Content Mastery

\begin{tabular}{lrl}
\hline \multicolumn{1}{c}{$\begin{array}{c}\text { Content } \\
\text { Mastery }\end{array}$} & $\begin{array}{c}\text { Range of } \\
\text { Average } \\
\text { Score }\end{array}$ & Category \\
\hline $\begin{array}{l}\text { History of } \\
\text { Islamic }\end{array}$ & $61-80$ & Moderate \\
$\begin{array}{l}\text { Culture } \\
\text { Fiqh }\end{array}$ & $61-80$ & Moderate \\
$\begin{array}{l}\text { Qur'an Hadits } \\
\text { Aqidah } \\
\text { Akhlak }\end{array}$ & $81-100$ & High \\
\hline
\end{tabular}

The above achievement showed that the mastery of Qur'an-Hadits content and of Aqidah Akhlak content had been higher than that of Fiqh content and History of Islamic Culture content. Compared to the teachers' terms of service, in average the teachers who mastered the contents had been young and the range in their terms of service had been 15 years old. Based on the opinion by Marsh \& 
Hattie (2002), this findings might be analyzed as follows: an individual who had been teaching between 5-15 years would be regarded as diversification and change. This type of teachers had the following characteristics: having experimentation to increase effectiveness, having quest for new challenges and having willingness to take up new responsibilities. The teachers in this stage would like to perform learning experiments in order to improve the effectiveness of the learning process that they underwent. In addition, the teachers in this stage would like to have new challenges and responsibilities.

The data in the study showed positive findings; the teachers whose terms of service range had been 15 years old scored higher than 70. Most of the teachers in this range implemented their content mastery by pursuing rich learning sources and one of such sources was the following textbooks: Tarbiyah Jihadiyah, Hakekat Tauhid and Aqidatul Awam for the learning process of Aqidah Akhlak; Sirah Nabawi and Islamic Encyclopaedia for the learning process of History of Islamic Culture; and Figh Sunnah, Fiqh 4 Mdzhab, Fiqh Sulaiman Rasyid and Fiqh Wanita for the learning process of Fiqh.

There were also some teachers who had been teaching for more than 15 years. This stage was regarded as Serenity and usually occurred when a teacher had been teaching for $15-30$ teachers. The teachers I this stage usually had the following characteristics: reduced career ambition, high levels of selfsufficiency and confidence and increased distance from students. However, they had high self-confidence.

The condition that had been explained above showed that the professional competencies that the Islamic Education teachers had already possessed were very low. On the other hand, according to the mandates in the Government Regulation Number 74
Year 2008 Article 3 Verse 7 it had been mentioned that: Professional competences are the teachers' competencies in mastering the knowledge in the domain of science, technology and/or art and culture that they teach and their knowledge should cover at least the mastery of:

a. In depth and in width learning materials according to the content standards of educational unit programs, subjects and/or subject groups that they will be teaching; and

b. Concepts and methods of relevant scientific discipline, technology and art that conceptually cover or are inherent to the educational unit programs, the subjects and/or the subject groups that the teachers will be teaching.

These norms suggested and mandated that the teachers' professional competencies should include two aspects namely the in depth and in width learning materials and concepts and methods of scientific discipline, technology or art. In order to achieve the norms under the rules that had been governed among the teachers, there should be a service of content reinforcement that the Institution of Teaching Staff Education held - formally, non-formally and informally - after a teacher had completed his or her undergraduate study.

This reinforcement should be pursued in order to train and to develop the teachers' profession, especially in terms of their commitment toward in depth and in width learning materials mastery as well as in terms of concepts and methods of scientific discipline, technology or art. The reason was that up to date the activities of Teacher Professional Training and Education (PLPG, Pendidikan dan Latihan Profesi Guru) had been more dominant in the aspect of pedagogical content knowledge. The description of this situation would be provided below: 
Table 11. PLPG Materials

\begin{tabular}{cclc}
\hline Code & Materials & $\begin{array}{c}\text { Number of Period } \\
\text { (Hour) }\end{array}$ \\
\hline A & General & Teacher Professional Development & 6 \\
B & Principal & Pedagogical Materials and Study & 32 \\
C & Workshop & Program Exploration & 30 \\
D & Peer Teaching & Learning Set Development Implementation & 20 \\
E & Local Written Test & Local Written Test & 2 \\
& & Number of Teaching Period & 90
\end{tabular}

The above table showed that the reinforcement of pedagogical content knowledge had still been dominant. This dominancy might be viewed from the learning set materials and their implementation, which had been more than $60 \%$. As a result, there had not been any differences in the content mastery among the teachers. Similarly, the Curriculum of Teacher Professional Education (PPG, Pendidikan Profesi Guru) that had been designed by the General Directory of Islamic Education provided the following description:

Table 12. The Structure of PPG Curriculum

\begin{tabular}{ll}
\hline No & \multicolumn{1}{c}{ Course } \\
\hline 1 & Study Program Material Exploration \\
2 & Learning Set Development \\
3 & Learning Programs \\
4 & Syllabus and Lesson Plans \\
5 & Materials, Media and Teaching Materials \\
6 & Learning Strategies \\
7 & Evaluation \\
8 & Learning Diagnose and Clinic Development \\
9 & Classroom Research \\
10 & ICT-Based Learning \\
11 & Education-Experiential Field Practice \\
\hline
\end{tabular}

The above table showed that the PLPG and the PPG materials had been more dominant in the aspect of teaching-learning process mastery reinforcement. Thereby, it might be stated that, among the real needs, the weakness in the content mastery among the teachers could not be made as the basis of designing the teacher professional education curriculum. Furthermore, it might be stated as well that the two activities of teacher professional development (PLPG and PPG) had less synergy with the content development as part of real needs among the teachers' professional environment.

Such condition might lower the students' learning achievement in the domain of Islamic Education due to the weak content mastery. This statement was asserted by the results of a study by Raudenbush \& Bryk (2002) that made use of hierarchical linear modeling (HLM) analysis; the results of this study showed a positive and significant relationship between the teachers' content knowledge and the students' learning achievement. The reason was that teaching had been complex social activities that involved the mastery toward teachers' knowledge, belief and attitude inside and outside the classroom. There was wide consensus that the teachers' knowledge regarding subjects had been very important: if the teachers did not understand the content knowledge of science then they would not be able to assist the students in developing their understanding toward the knowledge. The reason was that the teachers always combined two bodies of the knowledge. One of the bodies was the knowledge regarding the study program that they had been teaching, the one that did not only include the fact but also the logic toward the world of knowledge and toward the aspects that they understood. Then, the other body was the knowledge regarding the teaching practice that included communication with the students and how the students learned. This statement was supported by the opinion of Rymarz (2013) who stated, "Without adequate content knowledge teachers find it difficult to teach in an engaging and informed way." The teachers who did not have sufficient content 
knowledge would be difficult in performing interesting and informative teaching activities.

Looking at those situations, there should be continuous professional development program which had also been known as Continuing Professional Development (CPD) for the teachers and this program was not only limited to the PLPG and the PPG. According to Cordingley, Bell, Thomason, \& Firth (2005); Craft (2002); Kennedy (2005), the CPD had been a planned, continuous and lifelong process whereby teachers tried to develop their personal and professional quality and to improve their knowledge, skills and practice, leading to their empowerment, the improvement of their agency and the development of their organization and their pupils. The CPD process should be planned, be continuous and be lingering so that a teacher might strive to develop their personal and professional qualities and to improve their knowledge, skills and practice in order to be empowered. Through the reinforcement of both aspects, both the content knowledge and the pedagogical content knowledge turned the quality of teachers' learning process to be better and it would impact the students' quality. This statement might be reflected by the results of a stud by Ozden (2008), which stated that the results of this study emphasized that content knowledge had positive influence on pedagogical content knowledge. Content knowledge also influenced effective teaching practice. Content knowledge had positive impact toward pedagogical content knowledge and vice versa.

\section{CONCLUSION AND RECOMMENDATION}

The number of teachers who have participated in the academic competence test is 31 people from the State and the Private Madrasah Tsanawiyah around Surakarta dan Sukoharjo. This number is low because the schools have not been open in providing information regarding the number of teachers who have been teaching the Islamic
Education subjects. Then, only several teachers are willing to participate in the academic competence test and the other teachers only complete the test in the aspects that they teach. Therefore, there are differences in the number of subjects because the number of subjects is determined by the teachers who have participated in the academic competence test. In overall, the average score of Islamic Education materials has been 74 - which is quite low for a teacher and even there are teachers who have scored 47 ; the maximum score in this test is 100 . In terms of mean, the scores in the four subjects of Islamic Education, from the highest to the lowest academic competence test results are as follows: Qur'an - Hadits : 76.40; Fiqh : 76.40; History of Islamic Culture: 73.46; and Aqidah Akhlak : 72.40. The score in the content mastery of Qur'an - Hadits and Aqidah Akhlak has been higher than that of Fiqh and History of Islamic Culture.

The content mastery among the teachers should be reinforced by the LPTK, especially in the design of professional education curriculum both through the PLPG path and the PPG path. Similarly, the graduate study for the Islamic Education teachers should also reinforce the content mastery among the teachers and there should be another concentration in the graduate study programs that are in accordance to the components of Islamic Education namely Qur'an - Hadits, Fiqh, Aqidah Akhlak and History of Islamic Culture.

\section{REFERENCES}

Abdurrahmansyah, A. (2014). Kontribusi pendekatan pembelajaran konstruktivisme dalam meningkatkan kualitas pembelajaran PAI di sekolah. Ta'dib, 19(01), 111-122.

Azra, A., Afrianty, D., \& Hefner, R. W. (2007). Pesantren and madrasa: Muslim schools and national ideals in Indonesia. Schooling Islam: The Culture and Politics of Modern Muslim Education, 172-98. 
Cogill, J. A. (2008). Primary teachers' interactive whiteboard practice across one year: changes in pedagogy and influencing factors. King's College London (University of London).

Copur-Gencturk, Y., \& Lubienski, S. T. (2013). Measuring mathematical knowledge for teaching: a longitudinal study using two measures. Journal of Mathematics Teacher Education, 16(3), 211-236. Retrieved from http://link.springer.com/article/10.1007/ s10857-012-9233-0

Cordingley, P., Bell, M., Thomason, S., \& Firth, A. (2005). The impact of collaborative continuing professional development (CPD) on classroom teaching and learning. Review: How Do Collaborative and Sustained CPD and Sustained but Not Collaborative CPD Affect Teaching and Learning.

Craft, A. (2002). Continuing professional development: A practical guide for teachers and schools. Routledge.

Darling-Hammond, L. (2000). Teacher quality and student achievement. Education Policy Analysis Archives, 8, 1.

Darmadji, A., Zubaidah, S., Sibly, M. R., \& Andriansyah, Y. (2015). Islamic Education Teachers' Content Knowledge of Islamic Law Matters: A Study in Yogyakarta City. Mediterranean Journal of Social Sciences, 6(5), 441.

Fägerlind, I., \& Saha, L. J. (2016). Education and national development: A comparative perspective. Elsevier.

Gencturk, Y. C. (2012). Teachers' mathematical knowledge for teaching, instructional practices, and student outcomes. University of Illinois at Urbana-Champaign.
Gess-Newsome, J., \& Lederman, N. G. (2001). Examining pedagogical content knowledge: The construct and its implications for science education (Vol. 6). Springer Science \& Business Media.

Guskey, T. R. (2002). Professional development and teacher change. Teachers and Teaching, 8(3), 381-391.

Harris, J., Mishra, P., \& Koehler, M. (2009). Teachers' technological pedagogical content knowledge and learning activity types: Curriculum-based technology integration reframed. Journal of Research on Technology in Education, 41(4), 393-416.

Hill, H. C., Ball, D. L., \& Schilling, S. G. (2008). Unpacking pedagogical content knowledge: Conceptualizing and measuring teachers' topic-specific knowledge of students. Journal for Research in Mathematics Education, 372-400.

Jones, A., \& Moreland, J. (2006). The centrality of PCK in professional development for primary science and technology teachers: Towards schoolwide reform. New Teaching and Teacher Issues, 73-95.

Kennedy, A. (2005). Models of continuing professional development: a framework for analysis. Journal of In-Service Education, 31(2), 235-250.

Kleickmann, T., Richter, D., Kunter, M., Elsner, J., Besser, M., Krauss, S., \& Baumert, J. (2013). Teachers' content knowledge and pedagogical content knowledge: The role of structural differences in teacher education. Journal of Teacher Education, 64(1), 90-106.

Koehler, M. J., \& Mishra, P. (2005). What happens when teachers design educational technology? The development of technological pedagogical content knowledge. 
Journal of Educational Computing Research, 32(2), 131-152.

Kong, L. (2005). Religious schools: for spirit,(f) or nation. Environment and Planning D: Society and Space, 23(4), 615-631. Retrieved from http://journals.sagepub.com/doi/abs/10. 1068/d394

Loewenberg Ball, D., Thames, M. H., \& Phelps, G. (2008). Content knowledge for teaching: What makes it special? Journal of Teacher Education, 59(5), 389-407.

Marsh, H. W., \& Hattie, J. (2002). The relation between research productivity and teaching effectiveness: Complementary, antagonistic, or independent constructs? The Journal of Higher Education, 73(5), 603-641.

Mishra, P., \& Koehler, M. J. (2006). Technological pedagogical content knowledge: A framework for teacher knowledge. Teachers College Record, 108(6), 1017.

Munadi, M., Choiriyah, S., \& Alawiyah, N. (2016). Strategi meningkatkan mutu calon guru agama Islam. Jurnal Pendidikan Islam, 27(1), 35-46.

Niess, M. L. (2005). Preparing teachers to teach science and mathematics with technology: Developing a technology pedagogical content knowledge. Teaching and Teacher Education, 21(5), 509-523.

Ozden, M. (2008). The effect of content knowledge on pedagogical content knowledge: the case of teaching phases of matters. Educational Sciences: Theory and Practice, 8(2), 633-645.
Park, S., \& Oliver, J. S. (2008). Revisiting the conceptualisation of pedagogical content knowledge (PCK): PCK as a conceptual tool to understand teachers as professionals. Research in Science Education, 38(3), 261-284.

Prawat, R. S. (1992). Teachers' beliefs about teaching and learning: A constructivist perspective. American Journal of Education, 100(3), 354-395.

Putnam, R. T., \& Borko, H. (2000). What do new views of knowledge and thinking have to say about research on teacher learning? Educational Researcher, 29(1), 4-15.

Raudenbush, S. W., \& Bryk, A. S. (2002). Hierarchical linear models: Applications and data analysis methods (Vol. 1). Sage.

Rymarz, R. M. (2013). Direct instruction as a pedagogical tool in religious education. British Journal of Religious Education, 35(3), 326-341.

Schunk, D. H., Meece, J. R., \& Pintrich, P. R. (2012). Motivation in education: Theory, research, and applications. Pearson Higher Ed.

Shanahan, T., \& Shanahan, C. (2008). Teaching disciplinary literacy to adolescents: Rethinking content-area literacy. Harvard Educational Review, 78(1), 40-59.

Timperley, H., Wilson, A., Barrar, H., \& Fung, I. (2008). Teacher professional learning and development. 